\title{
SOSIAALITURVAN MUUTOS VAI JATKUVUUS?
}

\section{Työn vastaanottovelvollisuuden laajentaminen vuoden 1984 työttömyysturvalaissa}

\author{
Maija Absetz \\ FM, Helsingin yliopisto
}

\section{Työttömyysturva ja hyvinvointivaltio}

Vuoden 1984 työttömyysturvalaki on erityisen antoisa lähtökohta suomalaisen hyvinvointivaltion tutkimiselle, sillä se uudisti työttömyysturvaa perusteellisesti. Tässä yli vuosikymmenen verran valmistellussa merkittävässä uudistuksessa työttömyystuista tuli verotettavaa tuloa, tuet jaoteltiin perusturvaan ja ansioturvaan ja nämä tuet sisällytettiin saman lain alle. Käsittelen tässä artikkelissa sitä, miksi ja miten työn vastaanottovelvollisuutta laajennettiin vuoden 1984 työttömyysturvauudistuksessa $(602 / 84)^{1}$. Keskityn tarkastelemaan lakiin liittyviä valtasuhteita kolmikantamallin näkökulmasta. Kysyn, miten työmarkkinoiden keskusjärjestöt - Suomen Työnantajien Keskusliitto (STK) ja Suomen Ammattiliittojen Keskusjärjestö (SAK) - sekä parlamentaarisen lainsää- däntöprosessin viralliset osapuolet - hallitus ja eduskunta - vaikuttivat lainsäädäntöön.

Laajoissa sosiaaliturvaa koskevissa yleisteoksissa on korostettu sitä, että sosiaaliturvapalvelujen kasvukausi jatkui aina 1990-luvulle asti. ${ }^{2}$ Toisaalta sosiaalimenojen osuus bruttokansantuotteesta kasvoi laman ja työttömyyden kasvun seurauksena tämänkin jälkeen. ${ }^{3}$ Minna Van Gerven esittää väitöskirjassaan, että 1980luku edustaa työttömyysturvalainsäädännön osalta työttömyysturvan tason nousua ja parempaa saatavuutta. ${ }^{4}$ Hän tuo esille myös sen, että vuoden 1984 työttömyysturvalaki korostaa aiempia lakeja voimakkaammin vaatimusta tehdä työtä ja että se uhkaa työttömiä sanktioilla. ${ }^{5}$ Tämä artikkeli keskittyy Gervenin esiin nostamiin huomioihin työssäoloehtojen kiristymisestä vuoden 1984 laissa ja analysoi tar-

1 Työttömyysturvalaki 602 (1984), https://www.finlex.fi/fi/laki/alkup/1984/19840602.

2 Ks. esim. Anu Suoranta, Halvennettu työ: Pätkätyö ja sukupuoli sopimusyhteiskuntaa edeltävissä työmarkkinakäytännöissä (Tampere: Vastapaino, 2009), 13; Minna Gerven, The Broad Tracks of Path Dependent Benefit Reforms: A Longitudinal Study of Social Benefit Reforms in Three European Countries, 1980-2006 (Helsinki: Kela, Research Department, 2008), 175-188; Kyösti Urponen, ”Huoltoyhteiskunnasta hyvinvointivaltioon," teoksessa Armeliaisuus, yhteisöapu, sosiaaliturva: Suomalaisen sosiaalisen turvan historia, kirjoittanut Jouko Jaakkola, Panu Pulma, Mirja Satka ja Kyösti Urponen (Helsinki: Sosiaaliturvan keskusliitto, 1994), 257; Raija Julkunen, Suunnanmuutos: 1990-luvun sosiaalipoliittinen reformi Suomessa (Tampere: Vastapaino, 2001), 37, 57. Julkunen tosin huomauttaa, että instituutioiden uudelleenmuotoilu aloitettiin jo 1980-luvun puolivälissä, 1987 Holkerin (Kok.) hallituksen aikana.

3 Julkunen, Suunnanmuutos, 145.

4 Gerven, Broad Tracks.

5 Ibid., Luku 5.2.1. 
kemmin työssäoloehtojen kiristymisen muotoja ja syitä.

Vuoden 1984 työttömyysturvalakia on tutkinut aiemmin myös Kari Vähätalo. ${ }^{6}$ Hänen tutkimuksensa ei kuitenkaan ota juuri kantaa valtapoliittisiin näkökulmiin tai siihen, miksi lakiuudistus tehtiin ja miksi se oli sellainen kuin oli. Lain tarkasteluun jää myös aukkoja työttömyysturvan historiaa koskevissa yleisteoksissa. $^{7}$

Vuoden 1984 työttömyysturvalain ymmärtämisen kannalta mielenkiintoinen on työmarkkinajärjestöjä poliittisina voimina tarkasteleva Niklas Jensen-Eriksenin, Henrik Talan, Elina Kuorelahden, Aaro Saharin ja Maiju Wuokon teos Loputtomat kihlajaiset: Yritykset ja kolmikantakorporatismi Suomessa 1940-2020 (Helsinki: Kustannusosakeyhtiö Siltala, 2020). Se on kuitenkin yleisteos, eikä syvenny työmarkkinajärjestöjen toimintaan yksittäistapauksissa. Tämän artikkelin lähtökohtana on päinvastoin työmarkkinajärjestöjen toiminnan tarkastelu yksittäistapauksessa, vuoden 1984 työttömyysturvalain muodostamisen yhteydessä.

Tuoreissa väitöskirjoissa on tutkittu hyvinvointivaltion kohtaamaa kritiikkiä 1980-luvulla ja uusliberalismin vaikutuksia suomalaisessa yhteiskunnassa. ${ }^{8}$ Työttömyysturvan arviointi tästä näkökulmasta kaipaa kuitenkin täydennystä. Artikkelini täydentää tätä näkökulmaa käsittelemällä hyvinvointivaltion kohtaamaan kritiikkiä 1980-luvulla.

Suomen hyvinvointivaltio on liitetty pohjoismaiseen malliin ja sosialidemokraattiseen hyvinvointivaltioon, vaikka Suomen mallissa on myös omat erityispiirteensä. ${ }^{9}$ Työmarkkinoiden valtiollinen säätely tehdään pohjoismaisen mallin mukaisesti yhteistyössä työmarkkinajärjestöjen kanssa ja keskitettyjen neuvottelujärjestelmien avulla. ${ }^{10}$ Erityisesti työllisyyskysymyksiä koskevissa poliittisissa päätöksissä on yleensä kuultu myös työmarkkinajärjestöjä. Työmarkkinoihin liittyviä valtasuhteita tarkasteltaessa on syytä kiinnittää huomiota kolmikantamalliin, joka perustuu yhteistyöhön työmarkkinajärjestöjen ja valtion välillä. ${ }^{11}$ Hallitus on ollut keskeisemmässä roolissa korporatistisessa päätöksenteossa, ja eduskunta on toiminut kolmikantaisen mallin reunamilla. Eduskunnalla oli kuitenkin merkittävä rooli vuoden 1984 työttömyysturvalain muodostamisessa, ja se kuuluu siksi tämän artikkelin tutkimuskohteisiin. Valtakamppailu näiden osapuolien välillä ja sisällä näkyi koko työttömyysturvalainsäädäntöprosessin ajan.

Vuoden 1971 työllisyyslaki on vuoden 1984 lakia edeltänyt työttömyysturvaa koskeva laki, joten aloitan tarkastelun siitä. Käsittelen myös

6 Kari Vähätalo, Työttömät ja työttömyysturvauudistus: Tutkimus vuoden 1985 työttömyysturvaundistuksen työvoima-ja sosiaaliturvapoliittisista vaikutuksista (Helsinki: Työvoimaministeriö, 1988).

7 Ks. esim. Urponen, "Huoltoyhteiskunnasta hyvinvointivaltioon," 252-257; Olli Kangas ja Tapani Paavonen, Suomen eduskunta 100 vuotta, vol. 8, Eduskunta hyvinvointivaltion rakentajana (Helsinki, Edita, 2006), 240-245.

8 Maiju Wuokko, "Markkinatalouden etujoukot: Elinkeinoelämän valtuuskunta, Teollisuuden keskusliitto ja liike-elämän poliittinen toiminta 1970-1980-lukujen Suomessa" (Väitöskirja, Helsingin yliopisto, 2016); Ville Yliaska, Tehokkuuden toiveuni: Uuden julkisjohtamisen historia Suomessa 1970-luvulta 1990-luvulle (Helsinki: Into, 2014); Sami Outinen, Sosiaalidemokraattien tie talouden ohjailusta markkinareaktioiden ennakointiin: Työllisyys sosiaalidemokraattien politiikassa Suomessa 1975-1998 (Helsinki: Into-Kustannus, 2015); Ilkka Kärrylä, "The Contested Relationship of Democracy and Economy: Debates on Economic and Industrial Democracy in Finland and Sweden, 1960s-1990s" (Väitöskirja, Helsingin yliopisto, 2019).

9 Pertti Koistinen, Työ, työvoima ja politiikka (Tampere: Vastapaino, 2014), 74-75. Pohjoismainen malli edustaa liberaalin markkinatalouden mallia enemmän koordinoidun markkinatalouden ideaalia. Koistinen, Työ, $72-73$.

10 Koistinen, Työ, 75.

11 Markku Mansner, Suomalaista yhteiskuntaa rakentamassa: Suomen työnantajain keskusliitto 1980-1992 (Helsinki: Elinkeinoelämän keskusliitto, 2005), 22. 
olennaisia vuosien 1971 ja 1984 välillä syntyneitä lakiuudistuksia ja komiteanmietintöjä. Täydennän kuvaa Helsingin Sanomien uutisoinnilla ja työmarkkinajärjestöjen arkistojen asiakirjoilla. Pidempi ajanjakso mahdollistaa syvemmän ymmärryksen aikakaudesta. Artikkelia voi kutsua pitkittäistutkimukseksi. Lisäksi kyseessä on laadullinen tapaustutkimus, jonka tarkoituksena on täydentää tietämystä tarkasteltavan ajankohdan aatemaailmasta.

\section{Työmarkkinajärjestöt \\ työttömyysturvaa säätämässä}

Kolmikantamalliin vaikuttivat kylmän sodan ilmapiiri ja yleinen vasemmistovirtaus, joka maassa vallitsi vuoden 1984 työttömyysturvalain säätämisen aikoihin. Kokoomus oli pidetty oppositiossa vuoden 1970 suuresta vaalivoitostaan huolimatta ja sen jälkeenkin saavuttamistaan eduskuntavaalimenestyksistä riippumatta aina vuoteen 1987 asti. Sosialidemokraatit puolestaan pitivät tiukasti kiinni pääministerin paikasta. Lisäksi tasavallan presidentin puoluetausta vaihtui vuonna 1982 Urho Kekkosen keskustapuoluelaisuudesta Mauno Koiviston sosialidemokratiaan. Erityisesti juuri sosialidemokraattien asema näytti vahvalta.

1970-luvun öljykriisit ${ }^{12}$ jättivät jäljet vasemmistolaisiin aatteisiin. Euroopassa, mukaan lukien Suomessa, ja Yhdysvalloissa hyvinvointivaltioiden ja keynesiläisen talouspolitiikan kritiikki sai uutta pontta öljykriisien aloittamasta myllerryksestä. ${ }^{13}$ Tämä ilmeni myös Suomen sosialidemokraattisen puolueen (SDP) toiminnassa, sillä se alkoi pitää kilpailukyvyn turvaamista ensisijaisena vuodesta 1975 eteenpäin. ${ }^{14}$ Tämä SDP:n näkemys levisi suuremman yleisön tietoisuuteen vuonna 1977 pidetyn ns. Korpilammen konferenssin seurauksena. ${ }^{15}$ Liike-elämä ja poliittinen oikeisto myönsivät sosiaaliturvan tarpeellisuuden ja hyvinvointipalvelujen kasvun, kun taas poliittinen vasemmisto ja ammattiyhdistysliikkeet hyväksyivät taloudelliset välttämättömyydet. ${ }^{16}$ Hyvinvointivaltion kohtaamasta kritiikistä huolimatta julkisten menojen osuus bruttokansantuotteesta kasvoi Suomessa vuosien 1982 ja 1986 välillä 4 prosenttiyksikköä. ${ }^{17}$ Julkiset menot kasvoivat säästämistoiveista huolimatta suurien sosiaalipoliittisten uudistusten, kuten peruskoulu-, terveys- ja päivähoitojärjestelmien luomisen takia. ${ }^{18}$

Öljykriisien taloudelliset vaikutukset heijastuivat Suomessa aina vuoteen 1982 asti, jonka jälkeen alkoi vahva talouskasvu. ${ }^{19}$ Työttömyys laski parhaimmillaan kolmen prosentin tasolle 1980-luvulla, mutta työllisyys ei kuitenkaan palautunut öljykriisiä edeltäneelle tasolle. ${ }^{20}$

12 Läntinen maailma kohtasi toisen maailmansodan jälkeen pahimman talouskriisinsä, kun arabimaiden kauppasaarto Israelia tukevia maita vastaan nosti öljyn hintaa reilusti vuonna 1973. Maiju Wuokko, "Riitaisa liitto 1956-1991," osa 2 teoksessa Loputtomat kihlajaiset: Yritykset ja kolmikantakorporatismi Suomessa 1940-2020 (Helsinki: Kustannusosakeyhtiö Siltala, 2020), 200.

13 Yliaska, Tehokkuuden toiveuni, 70-77.

14 Sami Outinen, "From Steering Capitalism to Seeking Market Acceptance: Social Democrats and Employment in Finland," Scandinavian Journal of History 42, no. 4 (June 2017): 392-395, https://doi.org/10.108 $0 / 03468755.2017 .1336599$.

15 Ibid.

16 Maiju Wuokko, "The curious compatibility of consensus, corporatism, and neoliberalism: The Finnish business community and the retasking of a corporatist welfare state," Business History (April 2019): 7, https://doi.org/10.1080/00076791.2019.1598379.

17 Outinen, From Steering, 397.

18 Ibid.

19 Wuokko, "Riitaisa liitto," 238.

20 Maija Absetz ja Lotta Pirhonen, ”Tilastoaineisto: Työllisyys ja työttömyys Suomessa 1900-2017" (julkaisematon käsikirjoitusluonnos, 12.2.2019), Excel-tiedosto. 
Öljykriisien aikaan 1970-luvulla oli myös käynnissä rakennemuutos, mikä ilmeni siinä, että väestö kouluttautui, kaupungistui ja työllistyi. ${ }^{21}$ Automaation lisääntyessä ja koulutuksen yleistyessä tarjolla olevat työpaikat olivat aikaisempaa vaativampia ja erikoistuneempia. ${ }^{22}$ Osa työttömistä ei päässyt mukaan uuteen talouskasvuun ja heistä tuli pitkäaikaistyöttömiä.

Työttömyyden muuttunut rakenne oli vahvistanut usean vuosikymmenen ajan tarvetta muuttaa lainsäädäntöä muun muassa työttömyysturvan osalta. ${ }^{23}$ Eduskunnan päätöksentekovaikeuksien takia aloite oli siirtynyt sosiaalipoliittisissa asioissa työmarkkinajärjestöille jo 1950-luvun lopussa. ${ }^{24}$ Työttömyysturvalain uudistus onnistui vasta kolmikantaisen sopimisen myötä 1980-luvun alussa.

Kolmikantainen sopiminen houkutteli kaikkia korporatistisen järjestelmän osapuolia, mutta ei tasapuolisesti. SAK koki olevansa vahvoilla kolmikantaisessa sopimisessa1980-luvun alussa, ja sillä olikin tällöin paljon tavoitteita työelämän laadulliseksi parantamiseksi. ${ }^{25}$ Toisaalta SAK:n asenne keskitettyihin tulopoliittisiin kokonaisratkaisuihin ei ollut ongelmaton. Kun SAK muutti sääntöjään vuonna 1969, sen jäsenliittojen ei tarvinnut enää pyytää siltä erikseen lakkolupaa. Jäsenliitot saattoivat ottaa myös entistä itsenäisemmän linjan työehtopolitiikassa sääntömuutoksen jälkeen. Keskitettyihin ratkaisuihin perustuva tulopolitiikka sopi huonosti yhteen sen kanssa, että ammattiliitoista alkoi tulla riippumattomam- pia. Lisäksi SAK jakaantui voimakkaasti sosialidemokraatteihin ja kansandemokraatteihin, joilla oli osin erilaiset päämäärät ja keinot. Yksi suurimmista käytännön eroista näiden kahden SAK:n siiven välille syntyi siitä, millä tavoin ne suhtautuivat työehtosopimusten aikana tapahtuviin lakkoihin neuvottelujen painostuskeinona. 1970- ja 1980-luvuilla Suomessa lakkoiltiin erityisen paljon, mikä hiersi neuvottelujärjestelmän uskottavuutta ja sen osapuolien keskinäisiä välejä. ${ }^{26}$

STK oli samaan aikaan tyytymätön tulopoliittisiin kokonaisratkaisuihin. Se olisi halunnut enemmän liittokohtaista sopimista. Kokonaisratkaisujen etu oli kuitenkin työnantajien näkökulmasta se, että ne pitivät palkankorotukset maltillisina. Toisaalta kokonaisratkaisujen toimivuutta murensivat teollisten alojen vetämät palkkaliukumat eli palkankorotusten ylittäminen yli sopimusten, liittojen irtautuminen kokonaisratkaisuista sekä laittomat lakot sopimusten jälkeen. Keskustelu työmarkkinajärjestöjen pelisäännöistä ja erityisesti villien lakkojen hillitseminen oli työnantajien tavoitelistalla koko 1970-luvun. STK tavoitteli korkeita lakkosakkoja, jotta lakkoilu vähentyisi. $^{27}$

Sitä, että työttömyysturvasta tuli iso kysymys vuoden 1984 tulopoliittisella kierroksella, selittää SAK:n toive uudistaa työttömyysturvalainsäädäntöä. ${ }^{28}$ STK sen sijaan kritisoi sosiaalipoliittisten päätösten ottamista mukaan kokonaisratkaisuihin, mutta halusi kuitenkin vaikuttaa niitä koskevaan lainsäädäntöön. ${ }^{29}$

21 Wuokko, "Markkinatalouden etujoukot," 84.

22 Arla Marttila, "Aktivointipolitiikka yhteisöreaktiona" (Pro gradu -tutkielma, Helsingin yliopisto, 2016), 24.

23 Hallituksen esitys työttömyysturvalaiksi ja eräiksi siihen liittyviksi laeiksi 38/1984, 14. Jatkossa HE 38 (1984).

24 Kangas, Eduskunta, 241.

25 Tapio Bergholm, Tulopolitiikan aika, vol. 2, Laatua ja vapaa-aikaa: Suomen Ammattiliittojen Keskusjärjestö vuodesta 1977 (Porvoo: Suomalaisen Kirjallisuuden Seura, 2018), 352.

26 Ritva Savtschenko, Kompuroiden korporatismissa: Eheytyneen SAK:n ristipaineet suomalaisessa korporatismissa 1968-1978 (Omakustanne, 2015), 142.

27 Ibid., 141.

28 Bergholm, Tulopolitiikan aika, 356.

29 Wuokko, "Riitaisa liitto," 256-258. 
Työnantajakeskusjärjestön pyrkimys vaikuttaa tulevaan työttömyysturvalakiin näkyi jo ennen tulopoliittisia neuvotteluja. STK:n muistio "Sosiaalipolitiikan suuntaviivat 1980-luvulla" ja työttömyysturvakomitean mietintö vuodelta $1979^{30}$ ajoittuvat samoille ajoille ja ovat sisällöltään samankaltaisia. Omavastuun kehittäminen, työnteon kannattavuuden korostaminen ja työmotivaation säilyttäminen olivat molemmissa keskeisiä tavoitteita työttömyysturvan osalta. ${ }^{31}$ STK:lla vaikuttaa olleen SAK:ta enemmän valtaa kyseisessä työttömyysturvakomiteassa, sillä yksi mietinnön kirjoittajista oli työnantajien jäsen, kun taas työntekijöiden puolelta mukana oli vain yksittäisten liittojen jäseniä asiantuntijoina.

Seuraava työttömyysturvakomitea seurasi yleisellä tasolla vuoden 1979 mietintöä mutta otti enemmän kantaa yksityiskohtiin ja käytännön toteutukseen. Komitean puheenjohtaja Pekka Morri oli siirtynyt vuonna 1977 Kansaneläkelaitoksen johtajaksi SAK:n sihteerin paikalta. ${ }^{32}$ Työmarkkinajärjestöjen ja valtion toiminnan yhteys näkyi niin asiantuntijoissa kuin komiteanmietinnön kirjoittajissakin, mutta vielä selkeämmin Morrin siirtymisessä merkittävästä asemasta SAK:ssa Kelan johtoon. Toimikunnan työskentely johti vuoden 1982 työttömyystoimikunnan mietinnän syntyyn. ${ }^{33}$ Sen kirjoittajat ilmaisivat suoraan, että mietintö on pitkälti Morrin käsialaa. ${ }^{34}$ Myös tämä mietintö on selvästi yhteneväinen SAK:n tavoitteiden kanssa, mutta on silti vaikea arvioida, kumpi järjestö vaikutti enemmän sen sisältöön. Molemmilla oli toimijoita komitean avaintehtävissä. Ilmeistä silti on, että kummallakin keskusjärjestöistä oli vaikutusvaltaa työttömyysturvalain valmisteluvaiheessa.

Vuoden 1984 työttömyysturvauudistuksen suuntaviivat määrittyivät saman vuoden tulopoliittisissa neuvotteluissa, joiden tunnustelut alkoivat SAK:n kanssa vuoden 1983 lopulla. ${ }^{35}$ Vuoden 1984 alussa tuloneuvottelut olivat jämähtäneet paikoilleen, ja saman vuoden helmikuussa SAK ja sen jäsenliitot toimittivat suunnitelmat työnseisauksia koskevat suunnitelmat sen varalta, ettei neuvotteluissa päästäisi tulokseen maaliskuun alkuun mennessä. ${ }^{36}$ Toisin kuin SAK olisi toivonut, tulopoliittinen selvitysmies Matti Pekkanen "melkein puhtaan matemaattisesti halkaisi riidan keskeltä" keskusjärjestöjen vaatimusten väliltä. ${ }^{37}$

Vuoden 1984 tulopoliittinen kokonaisratkaisu, joka oli voimassa vuoteen 1986 asti, hyväksyttiin työmarkkinajärjestöjen kesken Pekkasen ehdottaman ratkaisun mukaisesti. Palkkoja korotettiin yhteensä 6,8 \%, työaikaa lyhennettiin ja lakkosakkoja korotettiin työnantajien eduksi reilusti. Sosialidemokraattien eduskuntaryhmän puheenjohtaja Olli Helminen summasi tulosta Helsingin Sanomissa seuraavasti:

30 Jatkossa KM 27 (1979).

31 KM 27 (1979); Suomen työnantajien keskusliiton pöytäkirja 448/78, liite 2, Sosiaalipolitiikan suuntaviivat 1980-luvulla, 28.9.1978, Suomen työnantajain keskusliitto (STK), Elinkeinoelämän keskusarkisto (ELKA), Mikkeli.

32 Bergholm, Tulopolitiikan aika, 56.

33 Jatkossa KM 34 (1982).

34 KM 34 (1982), 170.

35 Bergholm, Tulopolitiikan aika, 362-363.

36 SAK toi neuvotteluihin mukaan vaikeat kysymykset työajan lyhennyksestä, työttömyysturvan uudistuksesta ja matalapalkkamallista. SAK:n ja STK:n puolelta mukaan tulivat kysymykset työajan joustoista, liikkuvuudesta ja laittomien lakkojen hyvityssakoista. Näkemyksistä pidettiin tiukasti kiinni molemmin puolin. Bergholm, Tulopolitiikan aika, 376, 386.

37 "Pekkanen varasti laakerit," Muut lehdet, Helsingin Sanomat (HS), 7.5.1984, Päivälehden Arkisto (PA), Helsinki; Bergholm, Tulopolitiikan aika, 390. 


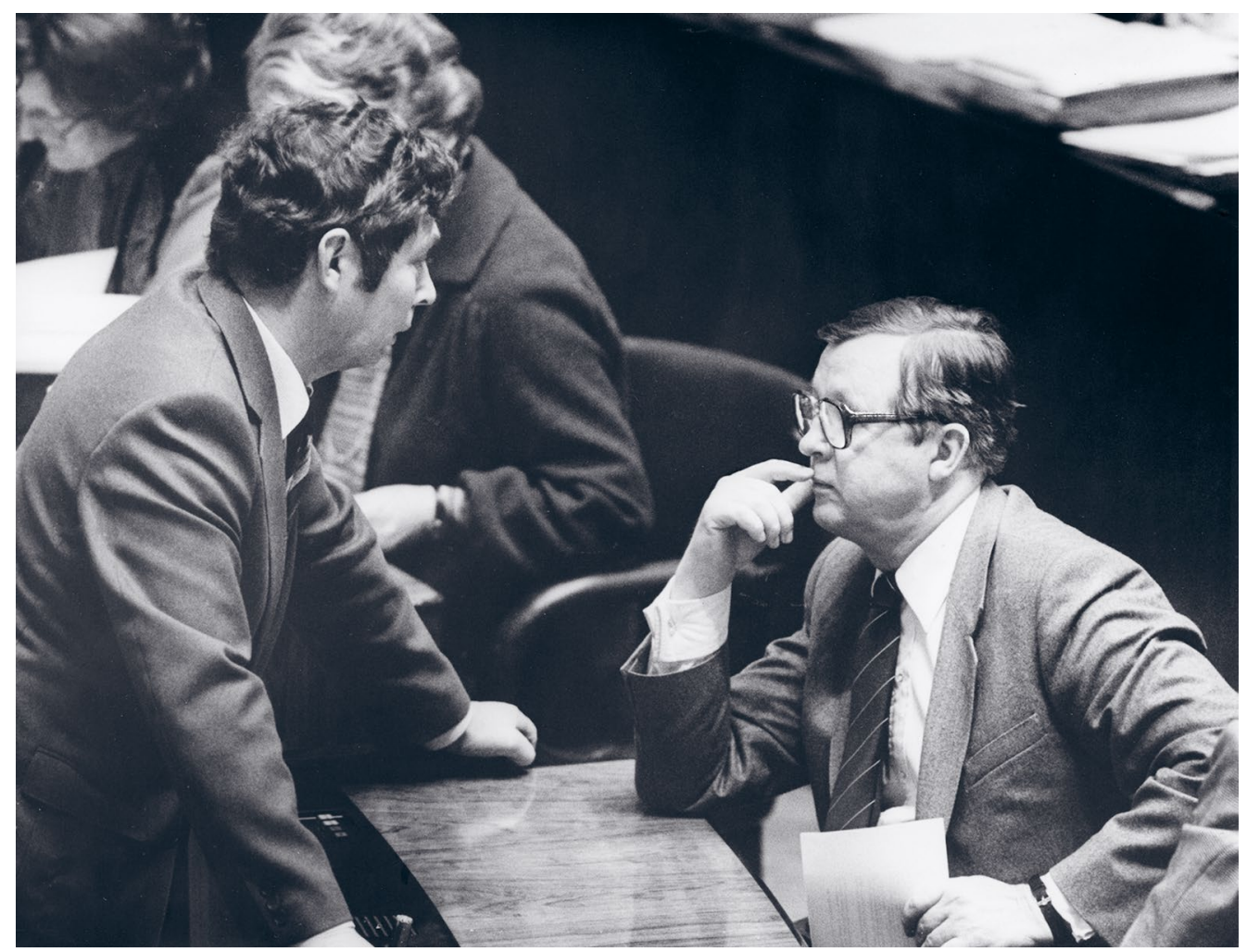

SKDL esitti välikysymyksen työttömyysturvasta vuonna 1984. Kuvassa sos.dem. eduskuntaryhmän puheenjohtaja Olli Helminen ja pääministeri Kalevi Sorsa eduskunnassa välikysymyksen käsittelyn aikaan. Kuva: Kalevi Keski-Korhonen / Työväen Arkisto.

Lakkosakkojen nostaminen oli työnantajien ehto keskitetyn ratkaisun syntymiselle. Emme ole tyytyväisiä hyvityssakkojen korotukseen, mutta ymmärrämme sitä koskevan päätöksen olevan osan kokonaisuutta, jonka purkaminen vaarantaa työväenliikkeen kannalta tärkeiden tavoitteiden toteutumista. ${ }^{38}$

SAK sai merkittävän laadullisen uudistuksen läpi, mutta hintana oli se, että työnantajat saivat mukaan sopimukseen oman pitkän aikavälin tavoitteensa - lakkosakkojen lähes kymmenkertaisen korotuksen.
Työttömyysturvan perusturvan summaksi sovittiin 70 markkaa päivässä ja ansio-osan kattavuudeksi $45 \%$ palkasta. ${ }^{39}$ Perusturvan nousu oli suurimmillaan 28,50 markkaa. ${ }^{40}$ Siinä missä aiemman kassalain mukaan ansio-osan kattavuus oli enimmillään kolme neljäsosaa ja kattona oli 53 markkaa perheettömälle, katto nousi uudistuksen myötä 90 prosenttiin aiemmasta tulotasosta. ${ }^{41}$ Absoluuttinen markkamääräinen katto katosi ansioturvasta kokonaan. ${ }^{42}$ Ansioturva sidottiin aikaisempaa vahvemmin tulotasoon, mutta taso myös heik-

38 "SDP:n Olli Helminen: Lakkosakon vaativat työnantajat ja porvari," Kotimaa, HS, 17.3.1984, PA.

39 Bergholm, Tulopolitiikan aika, 392.

40 HE 38 (1984), 7. Laskettu perheettömän saamasta työttömyysturvasta. Aiemmassa laissa perusturvan tasoon vaikutti myös asuinpaikkakunta. Sitä ei otettu enää huomioon uudistetussa perusturvassa.

41 HE 38 (1984), 7. Laskettu perheettömän saamasta työttömyysturvasta.

42 Työttömyysturvalaki 602 (1984), luku 6, 23\$. 
keni työttömyyden jatkuessa. Perusturva nousi prosentuaalisesi suhteessa vanhaan.

Vuoden 1983 eduskuntavaalit niukasti voittanut SDP piti pääministerin paikkansa $\mathrm{Ka}$ levi Sorsan johdolla, vaikka porvaripuolueet - Keskustapuolue, Suomen Maaseudun Puolue (SMP) ja Ruotsalainen kansanpuolue (RKP) - muodostivat hallituksen enemmistön. ${ }^{43}$ Yksi yllätysvoittajista oli SMP, joka sai 10 paikkaa lisää eduskuntaan. Se vei ne lähinnä Suomen Kansan Demokraattisen Liiton (SKDL) edustajilta. ${ }^{44}$ Sorsan johtaman hallituksen keskeiset talouspoliittiset tavoitteet olivat inflaation hillitseminen, kilpailukyvyn turvaaminen ja työttömyyden supistaminen. ${ }^{45}$ Tulopoliittinen sopiminen näytti hallitukselle keinolta päästä talouspoliittisiin tavoitteisiin. ${ }^{46}$ Hallituksella oli omia sisäisiä riitojaan tulopolitiikasta neuvoteltaessa. Ongelmia aiheuttivat erityisesti Keskustapuolueen ja SDP:n eroavat käsitykset työttömyysturvan hoidosta. ${ }^{47}$ Keskustapuolue, RKP ja SMP julistivat yhdessä ohjelman, jossa ne vastustivat SDP:n tukemaa ansiosidonnaista työttömyysturvaa. ${ }^{48}$ $\mathrm{Ne}$ olisivat lähteneet ennemmin perusturvan kehittämisen kannalle kuin vahvistamaan ammattiliittoihin pohjautuvaa kassajärjestelmää.

Hallituksen esitys työttömyysturvalaiksi jatkoi parikymmentä vuotta jatkunutta sosiaalisen korporatismin linjaa, jossa työmarkkinajärjestöt sopivat aluksi asioista, minkä jälkeen tulos vietiin eduskunnan päätettäväksi. ${ }^{49}$ Hallituksen esityksessä työvoiman liikkuvuut- ta koskeva ehto muutettiin lievemmäksi kuin mitä Pekkanen oli ehdottanut, jotta muut hallituspuolueet saataisiin esityksen taakse. ${ }^{50}$ STK väitti, että muutokset vesittävät Pekkas-paperin, ja varoitti siitä, että sopimuksesta lipeäminen aiheuttaa särön hallituksen ja etujärjestöjen yhteistyöhön. ${ }^{51}$ Muutokset eivät myöskään hiljentäneet työmarkkinajärjestöjä kritisoivia kansanedustajia, vaikka työttömyysturvaan liittyvää hallituksen esitystä muutettiin ennen eduskuntaan saapumista ja myöhemmin eduskuntakäsittelyssä.

\section{Työn vastaanottovelvollisuutta laajennetaan (vai laajennetaanko?)}

Työn vastaanottovelvollisuus ei ollut uusi ajatus vuoden 1984 työttömyysturvalain syntyessä. Työttömällä oli myös edellisten lakien mukaan velvollisuus ottaa vastaan töitä ollakseen oikeutettu työttömyysturvaan. Eduskunnassa väiteltiin vuoden 1984 valtiopäiväkeskusteluissa siitä, pitäisikö velvollisuutta lisätä, pitää ennallaan vai jopa supistaa.

Työn vastaanottovelvollisuuden laajentamisesta puhuttiin julkisessa keskustelussa alueellisen ja ammatillisen liikkuvuuden lisäämisenä. Jo 1940-luvulla työttömyyskomitea oli ehdottanut, että työvoiman maantieteellistä liikkuvuutta lisättäisiin. ${ }^{52}$ Tällöin ratkaisuksi ehdotettiin suuria keskitettyjä työmaita, joihin työtä vailla olleet vietäisiin. Tätä ei uskallettu toteuttaa ennen 1950-luvun puoliväliä, jolloin suuret siirtotyömaaprojektit alkoivat

\footnotetext{
43 Bergholm, Tulopolitiikan aika, 356; Valtioneuvosto, "Hallituksen ja ministerit raportti," viitattu 11.11.2019, https://valtioneuvosto.fi/tietoa/historiaa/hallitukset-ja-ministerit/raportti/-/r/m1/63.

44 Bergholm, Tulopolitiikan aika, 355.

45 Ibid., 357.

46 Ibid.

47 "Esitys ehkä viikonvaihteessa," HS, 1.3.1984, PA.

48 Bergholm, Tulopolitiikan aika, 372.

49 Kangas, Eduskunta, 241.

50 Ibid.

51 "Työnantajat napisevat: Hallitus vei pohjan työttömien liikuttelulta," Kotimaa, HS, 3.4.1984, PA; "Kuka petti ketä," Pääkirjoitukset, HS, 7.4.1984, PA.

52 Marko Nenonen, Lapiolinjalla: Työttömät pakkotöissä 1948-1971 (Jyväskylä: Atena, 2006), 18.
} 
ja Itä- ja Pohjois-Suomen työttömiä siirrettiin Etelä-Suomen tieprojekteihin. ${ }^{53}$ Työttömyystöistä saatu avustus tuli palkan muodossa. Vasta 1960-luvun työllisyyslain myötä toteutui mahdollisuus raha-avustukseen ilman töitä, vaikka ajatus oli ollut vireillä vuosisadan alusta lähtien. ${ }^{54}$ Vielä 1960-luvulla työttömäksi ilmoittautunut voitiin määrätä töihin kotikunnan ulkopuolelle, vaikka siirtotyömaajärjestelmä romahti isossa mittakaavassa 1960-luvun alkuun mennessä. ${ }^{55}$ Vuoden 1971 työllisyyslaki lopetti työttömyystyöt ja siirtotyömaat lopullisesti. Rahakorvaus korvasi tällöin työttömyystyöt työttömyysturvan muotona. ${ }^{56}$ Pyrkimys työvoiman alueellisen ja ammatillisen liikkuvuuden lisäämiseen sisältyi vuoden 1971 työllisyyslakiin, mutta lakiin ei kuitenkaan sisältynyt ehdotuksia konkreettisista toimista asian suhteen. ${ }^{57}$ Vuoden 1982 komiteanmietinnössä ehdotettiin alueellisen ja ammatillisen liikkuvuuden laajentamista, jos työtä ei löydy. ${ }^{58}$

Hallituspuolueiden välillä vuoden 1984 uudistuksessa herätti kaikista eniten kiistaa ajatus alueellisen ja ammatillisen liikkuvuusvelvoitteen lisäämisestä. ${ }^{59}$ Näistä velvoitteista sai eniten huomiota alueellisen liikkuvuuden velvoite, millä tarkoitettiin velvollisuutta muuttaa toiselle paikkakunnalle työn perässä työttömyysturvan menettämisen uhalla. Suora muuttovelvoite puuttui vielä vuoden 1971 laista ja sen jälkeisistä asetuksista. ${ }^{60}$ Liikkuvuutta pyrittiin edistämään vanhassa laissa avustuksilla, ei pakotteilla. ${ }^{61}$ Käyttämieni lähteiden valossa ensimmäinen maininta velvollisuudesta muuttaa työn perässä löytyy vuoden 1979 komiteanmietinnöstä. Siinä ehdotetaan työttömyyskorvauksen epäämistä, jos hakija ei suostu muuttamaan työn perässä toiselle paikkakunnalle. $^{62}$

Tulopoliittisten neuvottelujen aikana Keskustapuolue vaati voimakkaasti, että alueellinen liikkumisvelvoite ei saa poiketa suuresti vanhasta lainsäädännöstä. ${ }^{63}$ Työnantajat eivät olisi kuitenkaan hyväksyneet Matti Pekkasen tulopoliittiseen ratkaisuun sisältyvää työttömyysturvaa ilman liikkuvuuspykälää. ${ }^{64} \mathrm{Hal}$ lituksen sisäisen kitkan takia pääministeri Sorsa pyysi neuvotteluvaraa liikkuvuuspykälään työmarkkinaosapuolilta. ${ }^{65}$ Hallitus pääsi keskenään sopuun vasta, kun liikkuvuudelle asetettiin enemmän rajoituksia kuin työnantajat olivat toivoneet. ${ }^{66}$ Hallitus lievensi muuttopakkoa lisää Pekkasen esityksestä, kun se vaati, että oman alueen työttömiä tulee pyrkiä hyödyntämään ennen kuin työntekijöitä siirretään alueelle muualta. ${ }^{67}$ Työvoimaministeri Urpo Leppänen (SMP) esitti, että käytännössä hallituksen edellyttämien rajoitusten mukaan ketään ei voi pakottaa muuttamaan hallituk-

53 Ibid., 28.

54 Jorma Kalela, Työttömyys 1900-luvun suomalaisessa yhteiskuntapolitiikassa (Helsinki: Valtion painatuskeskus, 1989), 48-49.

55 Nenonen, Lapiolinjalla, 21.

56 Ibid., 35-36.

57 Työllisyyslaki 906 (1971), 3\$.

58 KM 34 (1982), 52.

59 Kangas, Eduskunta, 241.

60 Suomen asetuskokoelma, 44/1980, 1004/1981; Suomen Säädöskokoelma 575/1983.

61 Suomen asetuskokoelma, 949/1971, 1ฐ.

62 KM 27 (1979), 31; KM 34 (1982), 54.

63 "Kepu aikoo pitää Sdp:tä lujilla," Kotimaa, HS, 8.3.1984, PA.

64 "Työttömyysturvan viimeistely jatkuu yksityiskohdista," Kotimaa, HS, 27.3.1984, PA.

65 Bergholm, Tulopolitiikan aika, 389.

66 Ibid., 372; "Ministerit sopuun pikavauhtia," Kotimaa, HS, 5.3.1984, PA.

67 "Hallitus pehmensi työttömien muuttopakkoa," HS, 30.3.1984, PA. 
sen esityksen perusteella. ${ }^{68}$ Vain suurissa kaupungeissa oli toivoa hyödyntää ensin omia työttömiä. Työttömien liikuttelua vaikeutti esimerkiksi se, että Helsinkiä vaivasi huutava asuntopula. Oman haasteensa neuvotteluihin toi myös se, että työnantajien mukaan pyrkimys hyödyntää vain paikallisia työttömiä vesittäisi koko liikkuvuuspykälän. ${ }^{69}$ Keskustapuolueen Mauri Pekkarinen valitteli, että työmarkkinajärjestöjen ja kokoomuksen johto vastusti jopa selkeitä parannuksia liikkuvuusasetuksiin. $^{70}$

Keskustelu alueellisesta liikkuvuudesta kytkeytyi keskusteluun työmarkkinajärjestöjen vallasta. SDP:ta lukuun ottamatta hallituspuolueissa valiteltiin SKDL:n tapaan, että alueellisen liikkuvuuden lisääminen on puhtaasti työnantajan etu. Mielenkiintoista on, että hallituspuolueidenkin jäsenet kritisoivat valtiopäiväkeskusteluissa hallituksen esitystä. Hallituspuolueiden edustajat katsoivat lain epäkohtien olevan työnantajien sanelemia. ${ }^{71}$ Keskustapuolueen Hannele Pokan mukaan hallitus joutui ostamaan rauhan työmarkkinoilla ja hyväksymään työttömyysturvauudistuksen osana kokonaisratkaisua. ${ }^{72}$ Sosialidemokraattinen ministeri Vappu Taipale muistutti, että laki ei ole pelkästään työmarkkinajärjestöjen sanelema: olihan hallitus tietoisesti poikennut Pekkas-sopimuksesta liikkuvuuden osalta jo hallituksen esityksessä. ${ }^{73}$

Pykälän vastustajat ja kriitikot puhuivat työttömien pakkomuutosta, kun taas pykälää puolustavat puhuivat työmarkkinoiden joustavuudesta. Työnantajat sanoivat, että tavoitteena ei ole pakkomuuttojärjestelmä vaan saada aikaan joustavuutta työmarkkinoille. ${ }^{74}$ SAK:n puheenjohtaja Pertti Viinanen totesi, että ay-liike ei hyväksy pakkomuuttoa, mutta tukee alueellista liikkuvuutta "silloin kun se johtaa turvattuun työpaikkaan ja parantuneisiin elinoloihin". ${ }^{75}$ Työmarkkinajärjestöt siis yrittivät kiinnittää huomion pois muuttovelvollisuudesta puhumalla joustavuudesta ja liikkuvuudesta. SDP:n edustajat toimivat lähes samoin, sillä he kutsuivat pakkomuuttoa työvoiman liikkuvuudeksi. Heidän mukaansa kritiikille ei ollut aihetta, sillä he pitivät uutta lakia vain vanhan käytännön jatkona. ${ }^{76}$ Tämä tulkinta jäi hallituksen esitykseen. ${ }^{77}$ Tulkinta ei kuitenkaan vastaa todellisuutta, sillä laki muuttui merkittävästi alueellisen liikkuvuuden osalta. Myös Helsingin Sanomissa tunnistettiin, että "voimassa olevissa säädöksissä tällaista muuttokehotusta ei ole." ${ }^{78}$ Uudistuksen myötä työstä kieltäytyminen johti työttömyysturvan menettämiseen. Tämä poikkesi selvästi vanhasta laista. Sinikka Hurskaisen (SDP) mukaan pelko siitä, että työttömän on pakko muuttaa paikkakunnalta toiselle, on turha, sillä aikaisempikaan laki ei pakottanut ketään muuttamaan, vaikka laki olisi sallinut sen. ${ }^{79}$ Muuttamispakko oli työvoimaviranomaisten päätöksen varassa eikä lukenut laissa. Lainsäädäntöä muutettiin, mutta SDP:n retoriikka pyrki häivyttämään muutoksen osaksi aikai-

68 Valtiopäivät (Vp) 1984, Pöytäkirjat 1, Ehdotukset, 10.4.1984, 765.

69 "Työnantajat napisevat: Hallitus vei pohjan työttömien liikuttelulta," Kotimaa, HS, 3.4.1984, PA.

70 Vp 1984, Pöytäkirjat 2, 1K, 21.6.1984, 1646.

71 Keskustalta muun muassa Sirkka-Liisa Anttila, Kauko Juhantalo, Mauri Pekkarinen ja Hannu Kemppainen,

SMP:Ita Timo Laaksonen, Vieno Eklund, Pentti Skön, RKP:lta Håkan Nordman ja Ole Norrback.

72 Vp 1984, Pöytäkirjat 1, Ehdotukset, 10.4.1984, 758.

73 Vp 1984, Pöytäkirjat 1, Esittely, 6.4.1984, 714.

74 "Työnantajat napisevat: Hallitus vei pohjan työttömien liikuttelulta," Kotimaa, HS, 3.4.1984, PA.

75 "Viinanen: työttömyyskorvauksen uudistusta ei saa lykätä," Kotimaa, HS, 14.4.1984, PA.

76 Vp 1984, Pöytäkirjat 1, Ehdotukset, 10.4.1984, 750, 759, 762, 767, 783.

77 HE 38 (1984), 21.

78 "Työttömien tulot nousevat," Kotimaa, HS, 10.3.1984, PA.

79 Vp 1984, Pöytäkirjat 1, Ehdotukset, 10.4.1984, 783. 
sempaa käytäntöä. Epävirallisen käytännön siirtäminen viralliseen lakiin oli toisaalta vanhan toiminnan jatkoa, toisaalta konkreettinen askel käytännön sementoimiseksi.

Pakkomuuton vastustajat vetosivat työttömän perusoikeuksiin, jotka piti turvata kustannuksista huolimatta. Velvollisuus muuttaa työn perässä työttömyysturvan menettämisen uhalla oli heidän mielestään hyväksyttävä peruste kutsua alueellista liikkuvuutta pakkomuutoksi. SKDL:n Pekka Leppäsen mukaan "[r]ahaa meillä on hoitaa nämä kysymykset" ${ }^{80}$ SKDL, Keskustapuolue ja SMP kyseenalaistivat muuttovelvollisuuden perustuslaillisuuden. ${ }^{81}$ SMP:n Pentti Skön ja keskustapuolueen Hannele Pokka vetosivat myös YK:n ihmisoikeuksien yleismaailmalliseen julistukseen, jossa puhutaan oikeudesta työhön, sen vapaaseen valintaan ja suojaan työttömyyttä vastaan. ${ }^{82}$ Hallitusmuodon mukaan Suomen kansalaisella oli oikeus valita asuinpaikkansa. Täten velvollisuus muuttaa työn perässä oli perustuslaillinen kysymys. Juuri kysymys muuttovelvollisuudesta johti lakiesityksen viemiseen myös perustuslakivaliokuntaan, mikä ei ollut vakiokäytäntö lakiehdotusten käsittelyssä. Perustuslakivaliokunnan mukaan muuttovelvollisuus todella oli ristiriidassa perustuslain kanssa, mutta siitä huolimatta sitä ei poistettu lopullisesta laista.

Kaikkien hallituspuolueiden piirissä esitettiin näkemyksiä siitä, että laki oli liian tiukka perheellisten osalta. Esityksen mukaan liikku- vuus kotipaikkakunnan ulkopuolelle on velvoitettu silloin, kun toinen vanhemmista voi käydä kotona päivittäin ja toisella on mahdollisuus käydä kotona viikoittain. ${ }^{83}$ Esitys edellyttää osittaista asumiseroa työttömyysturvan menettämisen uhalla siinä tapauksessa, että toinen puoliso on töissä ja toinen saa töitä kotipaikkakunnan ulkopuolelta. SDP:n Kerttu Törnqvist varoitti, että perheiden hajottaminen voi vähentää työttömyyttä, mutta "jonot mielenterveystoimistoissa ja sosiaalitoimistoissa kasvavat" ${ }^{84}$ Keskustapuolueen Juhani Alarannan mukaan liikkuvuuden lisäämät sosiaaliset ongelmat voivat osoittautua kalliimmaksi hoitaa kuin työttömyys. ${ }^{85}$

Kysymysten ryöppy eduskunnassa johti muuttovelvollisuuden tarkennukseen sosiaalivaliokunnassa. Tämän seurauksena perheellisten muuttovelvollisuutta selkeästi lievennettiin. ${ }^{86}$ Heidän osaltaan pidettiin huolta siitä, että "perhesuhteet eivät estä muuttamista". Toisin sanoen hallituksen esityksessä mainittu rajaus viikoittaisesta mahdollisuudesta käydä kotona poistettiin esityksestä. Lisäksi perheettömien tilaa parannettiin siten, että henkilö saattoi kieltäytyä työstä toisella paikkakunnalla, jos hänellä on siihen "painava henkilökohtainen syy". ${ }^{87}$ Tämä määritelmä on niin laaja, että perheiden muuttovelvollisuus katosi käytännössä. Keskustapuolueen eduskuntaryhmän puheenjohtaja Kauko Juhantalo otti kunnian perheellisten aseman parantamisesta itselleen eikä nähnyt rajoitusten jälkeen ongel-

80 Ibid., 757.

81 Ibid., 758; Vp 1984, Pöytäkirjat 2, 1K, 21.6.1984, 1628; Vp 1984, Pöytäkirjat 1, Ehdotukset, 10.4.1984, 791. Keskusta ilmaisi vuoden 1982 periaateohjelmassaan, että jokaiselle on turvattava mahdollisuus tehdä työtä ja hankkia toimeentulo kotiseudullaan. ”Keskustapuolueen periaateohjelma, 1982," viitattu 8.5.2020, https://www.keskusta.fi/loader.aspx?id=822283f3-c2cd-4580-a756-6a17758a6373.

82 Vp 1984, Pöytäkirjat 1, Ehdotukset, 10.4.1984, 748, 758.

83 HE 38 (1984), 37.

84 Vp 1984, Pöytäkirjat 1, Ehdotukset, 10.4.1984, 750.

85 Ibid., 794.

86 SoVM 8/1984.

87 Työttömyysturvalaki 602 (1984), 7 \$, 5mom. 
mia muuttovelvollisuudessa. ${ }^{88}$ Perheiden yhtenäisyys oli lakia säätäville tahoille tärkeämpää kuin työttömyyden vähentäminen liikkuvuutta lisäämällä.

Liikkuvuuskysymys nosti esiin alueelliset erot suurten kaupunkien, lähinnä Helsingin, ja pohjoisten syrjäseutujen välillä. Jälkiteollistuneessa Suomessa alkutuotanto laski 1960-luvun jälkeen jatkuvasti, kun taas palvelujen työllisyysosuus nousi. ${ }^{89}$ Työn rakenteen muuttuessa ongelmat heijastuivat työttömyyteen. Maaseudun alkutuotanto- ja jalostusalueiden työpaikkojen huvetessa työpaikkoja löytyi eniten palvelusektorilta kaupunkien kasvukeskuksista. Jo vuoden 1982 komiteanmietinnössä pelättiin liikkuvuuspykälien muutosten korostavan maan eri osien eriarvoisuutta. ${ }^{90}$ Sekä työvoimaministeriössä että sosiaali- ja terveysministeriössä ennustettiin, että ilmiö aiheuttaa köyhissä kunnissa muuttotappiota. ${ }^{91}$

Helsinki oli usein muuton kohde, ja pohjoiset syrjäseudut usein alkupiste. Työttömyys oli jo 1950-luvulta lähtien Itä- ja Pohjois-Suomessa keskimääräistä pahempaa. ${ }^{92}$ Vaikuttaakin siltä, että lain tavoite lisätä alueellista liikkuvuutta vastasi eniten kaupunkien työvoiman tarpeisiin. Keskustalaisten mielestä työpaikat olisi pitänyt viedä sinne, missä työntekijät ovat eikä toisin päin. ${ }^{93}$ Ennen siirtotyömaiden kautta työttömyyttä korjaamaan tarkoitetut työllisyystyöt sijoitettiin tarkoituksellisesti korkean työttömyyden alueille. Siirtotyömaat syntyivät kuitenkin epäsuhdasta, jossa työttö- mät asuivat syrjäseuduilla, ja työvoimapulasta kärsivä Etelä-Suomi jäi ilman kaipaamiaan teiden kunnostushankkeita. ${ }^{94}$ Vuoden 1984 keskustelussa sama ristiriita on yhä läsnä. Lapin lääniä edustaneen SDP:n kansanedustajan Aimo Ajon mukaan esimerkiksi Lapin ja Oulun lääneissä asuvat eivät voi lakiesityksen perusteella käydä riittävän usein kotona. ${ }^{95}$ Kokoomuksessa taas ajateltiin, että vanha työttömyysturvalaki oli epätasa-arvoinen helsinkiläisiä kohtaan. Saattoihan pohjoisemmassa saada työttömyysturvaa helpommin kuin pääkaupungissa, koska pohjoisemmassa oli vaikeampi löytää työtä. ${ }^{96}$ Keskustelu alueellisesta epätasa-arvosta toi esiin sen, että pohjoisen ja eteläisen Suomen ongelmat olivat eriytyneet toisistaan ja osin ristiriitaisia.

Tulopoliittisten neuvottelujen aikaan $\mathrm{Hel}$ singin Sanomien toimitus arvioi, että vastenmielisyys pakkomuuttoa kohtaan johtuu 1960-luvun kokemuksista valtion järjestämissä työttömyystöissä ja siirtotyömaiden parakkiasumisesta. ${ }^{97}$ Siirtotyömaiden parakit jouduttiin rakentamaan kiireessä, majoitus ja muonitus ontuivat ja työntekijöiden oli mahdotonta ennustaa töiden jatkumista. Työntekijöitä saatettiin irtisanoa ja palkata uudestaan mielivaltaisesti - ainakin jos asiaa katsoo heidän näkökulmastaan. ${ }^{98}$

Kumpaakin työttömyysturvakomiteanmietintöä kirjoittamassa ollut sosiaali- ja terveysministeriön hallitussihteeri Sakari Heikkilä väitti, että erityisesti kommunistit ja keskustalaiset

88 Vp 1984, Pöytäkirjat 1, Ehdotukset, 10.4.1984, 760.

89 Markus Kari, Suomen rahoitusmarkkinoiden murros 1980-luvulla (Helsinki: Into, 2016), 108.

90 KM 34 (1982), Vastalauseet IV, Laine, Anttila.

91 KM 34 (1984), Vastalauseet III.

92 Nenonen, Lapiolinjalla, 11.

93 Vp 1984, Pöytäkirjat 1, Ehdotukset, 10.4.1984, 758; Vp 1984, Pöytäkirjat 2, 1K, 21.6.1984, 1628; Vp

1984, Pöytäkirjat 1, Ehdotukset 10.4.1984, 763; ”Työttömyysturva ei saa rasittaa liikaa perheitä,” Kotimaa,

HS, 8.4.1984, PA.

94 Nenonen, Lapiolinjalla, 23.

95 Vp 1984, Pöytäkirjat 1, Ehdotukset, 10.4.1984, 759.

96 Ibid., 781.

97 Jorma Korhonen, "Muuttopakko pelottaa pohjoisen työttömiä," Sunnuntai, HS, 8.4.1984, PA.

98 Nenonen, Lapiolinjalla, 38, 50. 
ovat verranneet liikkuvuusvelvoitetta epäreilusti 1960-luvun siirtotyömaihin. ${ }^{99}$ Näin teki muun muassa Keskustapuolueen Hannele Pokka. ${ }^{100}$ Myös kokoomuksessa oli halua varmistaa, että uudistus ei johtaisi paluuseen 1960-luvun siirtotyömaajärjestelmään. ${ }^{101}$ Siirtotyömaihin liittyneet kokemukset vaikuttivat lähimuistissa vielä 1980-luvulla. Sopivan asunnon löytymistä lienee korostettu perusteluissa, jotta kenellekään ei jäisi epäselväksi ero 1960luvun malliin.

Lopulliseen lakiin kirjattiin velvollisuus vastaanottaa työtä "työssäkäyntialueen" eli kotipaikkakunnan ulkopuolelta, jos hakija on perheetön alle 50-vuotias, jos työnhakijalle voidaan löytää asunto ja jos työtä tarjotaan työehtojen mukaisesti. ${ }^{102}$ Perheellisten osalta esitettiin, että perhesuhteet eivät estä muuttamista. Huomioon otettiin sekä muut henkilökohtaiset syyt että asuinpaikkakunnan työllisyystilanne. Lakiin lisättiin liikkuvuusehto työttömyysturvan menettämisen uhalla, jota ei vanhassa laissa ollut. Mutta lakiprosessin aikana ehtoon lisättiin useita poikkeuksia, jotka estivät ehdon toteutumisen käytännössä. Eduskunnassa ei kyetty tai haluttu täysin luopua liikkuvuusehdosta. Suuria työnantajien toivomia joustoja työmarkkinoille liikkuvuuspykälällä ei saatu aikaan. Jos mikään ei käytännössä muuttunut, miksi pykälä ylipäänsä piti jättää lakiin? Keskustapuolueen Hannu Kemppainen ilmaisi, että liikkuvuuspykälästä ei voitu täysin luopua, koska "joidenkin arvovallalle se olisi ollut liian kova pala". ${ }^{103}$ Joillakin hän tarkoitti tietenkin työnantajien keskusjärjestöä.
Vaikka myös ammatillisen liikkuvuuden ehtoja kiristettiin, se sai paljon vähemmän huomiota kuin alueellinen liikkuvuus. Työttömyysturvaan kuuluva ammattisuoja tarkoitti mahdollisuutta kieltäytyä ammattia vastaamattomasta työstä menettämättä työttömyysturvaa. Koulutetulla ja työssä kokeneella työttömällä oli kolmen kuukauden ajan suurempi oikeus olla vastaanottamatta oman alan ulkopuolisia töitä kuin kouluttamattomalla työttömällä riippumatta siitä, kuuluiko työtön ansioturvan piiriin vai ei. Vuoden 1984 työttömyysturvalain mukaan ammattisuojan sai joko riittävän pitkällä työkokemuksella tai koulutuksen ja työkokemuksen yhdistelmällä. Työtön sai lain mukaan "kolmen ensimmäisen työttömyyskuukauden aikana kieltäytyä työstä, jota ei voida pitää hänen ammattitaitonsa huomioon ottaen hänelle sopivana" ${ }^{104}$

Ennen 1970- ja 1980-lukujen vaihdetta ammattisuojaa oli rajoitettu ajallisesti vain siltä osin, että perusturvaa koskeva työllisyysasetus oli rajannut ammattisuojan kolmeen työttömyyskuukauteen. ${ }^{105}$ Ammattisuojaan haluttiin kuitenkin muutoksia jo vuoden 1979 komiteanmietinnössä, jossa ehdotettiin ammattisuojan yhtenäistämistä. ${ }^{106}$ Yhtenäistämisen varjolla ammattisuojan aikarajoitusta alettiin tulkita tiukemmin: kolmen kuukauden aikaraja, joka oli aiemmin koskenut vain perusturvaa, katsottiin nyt koskevan kaikkia työttömyysturvamuotoja. Ansioturvajärjestelmään kuuluvien laissa rajoittamatonta ammattisuojaa nauttineiden työttömien oikeudet kaventuivat aiemmasta. Ammattisuojaan liittyi

99 "Hallitussihteeri Sakari Heikkilä: Työttömyysturva ei mullista työvoiman liikkuvuutta," Kotimaa, HS, 20.4.1984, PA.

100 Vp 1984, Pöytäkirjat 1, Ehdotukset, 10.4.1984, 758.

101 Ibid., 781.

102 HE 38 (1984), 37.

103 Vp 1984, Pöytäkirjat 2, 1K, 1632.

104 Työttömyysturvalaki 602 (1984), 7 \$, 3mom.

105 Työllisyysasetus 948 (1971), 9\$, 2 mom. Rajoitusehdotus: KM 34 (1982), 15; 53.

106 KM 27 (1979), 31. 
myös liikkuvuusehto. Hallituksen esityksessä sanottiin vuonna 1984, että työttömän tulisi ammattisuojasta huolimatta olla valmis ottamaan vastaan oman alan töitä muualta Suomesta tai muita töitä kotipaikkakunnalta, jos viranomainen arvioi, että oman alan töitä ei löydy kotipaikkakunnalta. ${ }^{107}$ Ammattisuojasta huolimatta työttömän oli valittava kotipaikkakunta tai ammattia vastaava työ työttömyysturvan menettämisen uhalla. Pykälä kirjattiin työttömyysturvalakiin hallituksen esittämällä tavalla. ${ }^{108}$

SKDL:n edustajat kutsuivat vuoden 1984 valtiopäiväkeskusteluissa ammattisuojan aikarajan rajoittamista kolmeen kuukauteen raivoisasti työttömyysturvan romuttamiseksi. ${ }^{109}$ Kansandemokraattien mukaan ammattisuojan tuli olla ajallisesti rajoittamaton niin ansioperustaisen työttömyysturvan kuin perusturvan osalta. ${ }^{110}$ SKDL:n eduskuntaryhmä jäi yksin mielipiteensä kanssa. Toisaalta sen edustama näkemys olisi tarkoittanut eri sääntöjä koulutetulle ja ei-koulutetulle väestölle, mikä sopi huonosti yhteen SKDL:n tasa-arvolla kantaansa perustelevan linjan kanssa.

Liikkuvuuskysymyksen perustuslaillisuudesta puhunut Hannele Pokka sanoi, että ammatin valintaa ei koske sama perustuslain turva kuin asuinpaikan valintaa. ${ }^{111}$ Keskustapuolueessa ammattisuojakin sai tosin kritiikkiä. Esimerkiksi Hannu Kemppainen piti ammatillista liikkuvuutta sinänsä hyvänä asiana, mutta kritisoi ammatin vaihtoon liittyvää pakkoa: hänen mukaansa "ei lääkäriä voi määrätä papiksi”. ${ }^{112}$ Mutta uuden lain perusteella lääkäri tuli työllistää koulutusta vaatimattomampaan ammattiin, vaikkapa siivoojaksi, jos oman alan töitä ei ollut tarjolla. Lain myötä nimenomaan hyvin koulutettujen ja hyväpalkkaisten ammattisuojaan tuli merkittäviä heikennyksiä. Kokoomus puolusti voimakkaasti ammatillista liikkuvuutta. Helge Saarikosken (Kok.) mukaan on parempi olla toisen alan töissä kuin oman alan työtön. ${ }^{113}$ Hänen puoluetoverinsa olisivat sisällyttäneet ammattisuojan piiriin koulutetut ilman työkokemusta, mutta kokoomuksessa ei kyseenalaistettu kolmen kuukauden aikarajaa. ${ }^{114}$ Eduskunnan toimintaa tutkineen Olli Kankaan mukaan ammattisuojan edustama oletus suomalaisen ammattirakenteen staattisuudesta ei enää vastannut työmarkkinoiden todellisuutta. Erilaistuvat ja epätyypilliset työsuhteet olivat yleistymään päin jo 1980-luvulla: Kuten Kangas kirjoittaa: "[n]opea ammattirakenteen muutos merkitsee sitä, että sellaiseen ammattiin, josta jäädään työttömäksi, ei yksinkertaisesti ole enää paluuta."115

Kaikista eniten työttömyysturvalakia kritisoivat SKDL:n edustajat. Heidän mukaansa laki heikensi ammatti- ja asuinpaikkasuojaa ja toi uusia velvollisuuksia jo olemassa olevien päälle. He myös kritisoivat voimakkaasti yhdessä SMP:n ja Keskustapuolueen edustajien kanssa työmarkkinajärjestöjen osallistumista lain valmisteluun. ${ }^{116}$ Erityisen purevaa SKDL:n kritiikki oli SAK:ta kohtaan. Sen mielestä SAK toimi porvariston jatkeena ajaessaan työmarkkinasopimuksen piiriin kuuluville kohtuuttoman hyviä ehtoja ja muille kohtuuttoman huo-

107 HE 38 (1984), 37.

108 Työttömyysturvalaki 602 (1984), $7 \$$, 4mom.

109 Vp 1984, Pöytäkirjat 1, Ehdotukset, 10.4.1984, 752; Vp 1984, Pöytäkirjat 2, 1K, 21.6.1984, 1613.

110 Vp 1984, Pöytäkirjat 2, 1K, 21.6.1984, 1613.

111 Ibid., 1628.

112 Ibid., 1632.

113 Vp 1984, Pöytäkirjat 1, Ehdotukset, 10.4.1984, 789.

114 Vp 1984, Pöytäkirjat 2, 1K, 21.6.1984, 1619. Myös Moisander (Kok.), Vp 1984, Pöytäkirjat 2, 1K, 21.6.1984, 1646.

115 Kangas, Eduskunta, 245.

116 Ibid., 243. 
noja. ${ }^{117}$ Toisaalta SKDL tuli samalla hyväksyneeksi perusturvan ja ansioturvan välisen kuilun. Se vastusti myös niitä muutoksia, jotka olisivat heikentäneet ansioturvan tasoa ja kestoa eli tuoneet molempien työttömyysturvien saamisen ehtoja lähemmäksi toisiaan.

RKP oli työttömyysturvakysymyksissä hallituspuolueista kaikista hiljaisin, mutta myös sen mielestä perusturvan ja ansioturvan välinen kuilu oli liian suuri. ${ }^{118}$

Keskustapuolueen suhde muuttovelvoitteeseen oli jatkoa puolueessa jo pitkään kannatusta saaneelle käsitykselle siitä, että työ on vietävä sinne missä työttömät ovat eikä toisinpäin. ${ }^{119}$ Maatalousväestö jäi suurelta osin työttömyysturvan ulkopuolelle, eikä ansiosidonnainen työttömyysturva tukenut heidän etujaan. Tämä selittää Keskustapuolueen ja SMP:n pyrkimykset vahvistaa perusturvaa ansioturvan sijaan. Kokoomus ja SDP pyrkivät sen sijaan SAK:n tuella parantamaan ansioturvan korvaustasoa, mikä johti turvan tasojen eriytymiseen. Tämän lisäksi ne tukivat työmarkkinajärjestövetoista lainsäädäntöä.

Puolueet jakaantuivat samalla tavoin kysymyksessä työttömien liikkuvuudesta. Aluksi Keskustapuolue ja SMP olivat SKDL:n kanssa samoilla linjoilla siinä, että muuttovelvollisuus on perustuslain vastainen, mutta ollessaan hallitusvastuussa samaiset kaksi puoluetta taipuivat ainakin periaatteellisella tasolla liikkuvuusvelvollisuuden laajentamisen puolelle. SKDL puolestaan pysyi loppuun asti lain suurimpana kriitikkona ja äänesti sitä vastaan. ${ }^{120}$ Kun kyseessä oli uudistuksen voimaan saattaminen ja samalla tulopoliittisen sopimisen toteutuminen, oli lain hyväksyminen lopulta myös kriitikoiden mielestä parempi vaihtoehto kuin se, että laki hylätään ja uutta lakia joudutaan odottamaan kymmeniäkin vuosia.

\section{Liian suuri kaatuakseen}

Työn vastaanottovelvollisuutta laajennettiin, koska työttömyysturvalaki ratkaistiin vaikeassa työmarkkinatilanteessa osana vuoden 1984 tulopoliittista kokonaisratkaisua. Oleellinen tekijä tässä oli työnantajien vaatimus alueellisen liikkuvuuden lisäämisestä ehtona työttömyysturvauudistukselle. Työttömyysturvalakia ei ollut onnistuttu uudistamaan ilman työmarkkinajärjestöjä. Riitaisat hallitukset eivät olleet päässeet yksimielisyyteen lain toteuttamisesta, vaikka uudistuksia oli valmisteltu pitkään. Työttömyysturvauudistus tuli osaksi vuoden 1984 tulopoliittista kierrosta SAK:n aloitteesta, mutta asiakirjoissa näkyy myös STK:n tavoite päästä vaikuttamaan työttömyysturvaan jo paljon ennen tulopoliittisen kierroksen alkua. Kolmikantaisen sopimisen ja tulopoliittisen mallin takia olemassa oli painetta saada laki läpi. Lain kaatumisella olisi ollut huomattavat seuraukset eduskunnan, hallituksen ja koko kolmikantaisen sopimisen uskottavuudelle. Kukaan ei halunnut ottaa vastuuta tulopoliittisen sopimuksen kaatumisesta, sillä yhteiskunnan toimivuuden kannalta olennaisia palasia oli sidoksissa sopimuksen syntyyn: palkankorotukset, työajan lyhentäminen, lakkosakkojen nosto ja työttömyysturvan uudistaminen. Eduskunnan käsittely sai kuitenkin aikaan muutoksia työttömyysturvalakiin.

Työn vastaanottovelvollisuuden laajentaminen herätti vastustusta niin hallituksessa kuin oppositiossakin. Liikkuvuuden lisäämistä vastustivat oppositio ja hallituspuolueet SDP:tä lukuun ottamatta. Hallituksen keskiryhmien eripura SDP:n kanssa johtui keskiryhmien kannanotosta SDP:n työttömyysturvamallia vastaan. Erityisesti Keskustapuolueen ja SMP:n esittämä kritiikki työttömyysturvauudistusta

117 Ibid.

118 Ibid., 241.

119 Ibid., 244.

120 Myös kolme sosialidemokraattia äänesti lakia vastaan. Ibid., 133. 
kohtaan hallituksen esityksen jälkeen lienee osoitus hallituksen sisäisestä valtataistelusta sekä pyrkimyksestä pelastaa kasvoja. Työmarkkinajärjestöt vaikuttivat olleen sopivia syntipukkeja. Niitä saattoi syyttää lain epäkohdista. Työttömyysturvauudistuksen kritisointi eduskuntakäsittelyssä johti sellaisiin lain muutoksiin, joihin työnantajat eivät olleet tyytyväisiä. Vaikuttaa kuitenkin siltä, että hallituspuolueiden esittämän kritiikin ei ollut tarkoitus kaataa koko uudistusta.

Vastaanottovelvollisuutta laajennettiin lisäämällä ammatillista ja alueellista liikkuvuutta. Vastaanottovelvollisuuden laajentamisen kannattajat käyttivät tässä yhteydessä sanaa "liikkuvuus". Sanaa käytettiin neutraalina ilmaisuna, ja sillä hämärrettiin sitä, että kyseessä oli työntekijöiden oikeuksia kaventava uudistus. Ammatillisen liikkuvuuden ehdot eivät muuttuneet aiemmasta laista muuten kuin kestonsa puolesta. Keston yhtenäistäminen kolmeen kuukauteen tarkoitti, että oikeutta ansioturvaan kavennettiin. Oikeuksien kaventamista voitiin peitellä esittämällä, että laki on jatkoa edeltäville laeille.

Alueellisen liikkuvuuden ehdot vietiin perustuslakivaliokunnan käsittelyyn, ja käytäntö todettiin perustuslain vastaiseksi. Tästä huolimatta alueellisen liikkuvuuden vaatimus jäi lakiin, mutta sitä kuitenkin lievennettiin ottamalla huomioon asuinolosuhteet. Lisäksi huomioitiin perhetilanne sekä työttömän henkilökohtaiset syyt, jotka saattoivat estää muuttamisen työn perässä. Laki otti työttömän tilanteen joustavammin huomioon kuin mitä alun perin Pekkasen ratkaisussa sovittiin tai hallituksen esityksessä ehdotettiin. Perheiden yhtenäisyys oli lopputulosta tarkastellessa lakia säätäville tahoille tärkeämpää kuin työttömyyden vähentäminen liikkuvuutta lisäämällä. Lisäksi kunkin kunnan työttömät piti saada töihin ennen kuin kuntaan siirrettiin työttömiä muualta. Nämä ehdot estivät alueellisen liikkuvuuden toteutumista, vaikka lakiin sisältyi velvoite muuttaa työn perässä. Arvioin, että liikkuvuuspykälä oli liian suurella vaivalla ai- kaan saatu kompromissi kolmikantaisessa sopimisjärjestelyssä, jotta siitä olisi täysin voitu luopua edes eduskunnassa. Toisaalta se oli siinä määrin radikaali muutos vanhaan nähden, ettei sitä olisi voitu hyväksyä sellaisenaan. Lopputuloksena oli periaatteellinen muutos, jolla oli vain vähän välittömiä seurauksia.

Työttömyysturvauudistusprosessin tarkastelu osoittaa, että työmarkkinajärjestöt olivat mukana lainvalmistelussa paljon voimakkaammin kuin mitä julkisuuden perusteella on saattanut luulla. Huomionarvoista on se, että molemmat työttömyysturvauudistusta käsittelevät komiteanmietinnöt pitivät sisällään lausunnot työn vastaanottovelvollisuuksien laajentamisesta liikkuvuutta lisäämällä. Monivuotinen komiteatyöskentely edelsi vuoden 1984 tulopoliittista ratkaisua, mikä kertoo siitä, että pyrkimyksiä laajentaa vastaanottovelvollisuutta oli ollut jo pidempään olemassa. Työnantajat puhuivat kaikista äänekkäimmin liikkuvuuden lisäämisestä, mutta se ei yksin selitä sitä, miksi heidän mielipiteensä päätyi lopulliseen lakiin. Vaikuttaminen komiteatyöskentelyyn ja julkinen painostus tulopolitiikan avulla ovat selittäviä tekijöitä tässä asiassa. Se, että SAK ja SDP eivät vastustaneet liikkuvuuden lisäämistä, osoittaa kuitenkin, että työttömyysturvauudistusta kohtaan oli hyväksyntää myös muissa kuin työnantajien piireissä. Yleinen asenneilmapiiri oli kääntynyt varaukselliseksi sosiaalimenojen kasvamista kohtaan sekä oikeistossa että vasemmistossa. Työttömyysturvan velvollisuuksien lisääminen oli kompensaatio sille, että turvan tasoa ei haluttu madaltaa.

Vuoden 1984 työttömyysturvauudistukseen liittyvät keskustelut sopivat yhteen aiemman tutkimuksen kanssa. Edeltävässä tutkimuksessa on tuotu esiin, että sosiaaliturva oli Suomessa 1980-luvulla uudelleenmäärittelyn kohteena. Vastaanottovelvollisuuden lisäämisestä käyty keskustelu oli osa pitkää jatkumoa, joka liittyi työttömän oikeuksien ja velvollisuuksien tasapainon hakemiseen osana sosiaalipolitiikkaa. Eduskunnassa oli tahoja, jotka 
pyrkivät lisäämään työttömän velvollisuuksia, ja tahoja, jotka pyrkivät vähentämään velvollisuuksia entisestään. Suomalaisessa työttömyysturvassa päädyttiin ratkaisuun, jossa velvollisuuksia lisänneet voimat voittivat. Turvan tason nosto ja velvollisuuksien lisääminen oli kompromissi, jonka avulla saatiin kaikki lakiin vaikuttaneet tahot mukaan.

Vaikka työttömyysturvassa oli siirrytty työllisyystöistä raha-avustuksiin 1960-luvulta lähtien, ajatus työvelvollisuuden ja työttömyysturvan yhteydestä säilyi vielä vuoden 1984 työttömyysturvauudistuksessa. Vuosien 19711984 välisenä aikana työttömyysturva ei ollut sidottu työllisyystöihin eikä turvan saaminen edellyttänyt liikkumista työn luokse. Vuoden 1984 työttömyysturvalakia voi pitää paluuna vanhaan työlinjaan, mutta toisaalta laki ilmentää yleiseurooppalaista mallia, joka korosti sosiaaliturvan vastikkeellisuuden merkitystä. Lisätutkimuksen avulla olisi mahdollista selvittää, kuinka paljon muutoksessa oli vanhoja ja kuinka paljon uusia aatteita.

\section{Lähteet}

\section{Alkuperäislähteet}

\section{Arkistolähteet}

Elinkeinoelämän keskusarkisto (ELKA), Mikkeli. Suomen työnantajain keskusliitto (STK). Pöytäkirjat hallitus.

\section{Painetut lähteet}

Valtiopäivät 1984. Pöytäkirjat 1, istunnot 1-46, 1.2.9.5.1984.

Valtiopäivät 1984. Pöytäkirjat 2, istunnot 47-89, 10.5.-27.9.1984.

Suomen asetuskokoelma.

Suomen säädöskokoelma.

\section{Elektroniset lähteet}

Valtioneuvosto. "Hallitukset ja ministerit -raportti." Viitattu 11.11.2019. https://valtioneuvosto.fi/tietoa/historiaa/hallitukset-ja-ministerit/raportti/-/r/ v2.
"Keskustapuolueen periaateohjelma, 1982." Viitattu 8.5.2020. https://www.keskusta.fi/loader.aspx?i$\mathrm{d}=822283 \mathrm{f3}-\mathrm{c} 2 \mathrm{~cd}-4580-\mathrm{a} 756-6 \mathrm{a} 17758 \mathrm{a} 6373$.

\section{Lehdistö}

Päivälehden arkisto (PA), Helsinki. Helsingin Sanomat (HS).

\section{Tutkimuskirjallisuus}

Absetz Maija ja Lotta Pirhonen. "Tilastoaineisto: Työllisyys ja työttömyys Suomessa 1900-2017.” Julkaisematon käsikirjoitusluonnos, 12.2.2019, Excel-tiedosto.

Bergholm, Tapio. Tulopolitiikan aika. Vol 2, Laatua ja vapaa-aikaa: Suomen Ammattiliittojen Keskusjärjestö vuodesta 1977. Porvoo: Suomalaisen Kirjallisuuden Seura, 2018.

Gerven, Minna van. The Broad Tracks of Path Dependent Benefit Reforms: A Longitudinal Study of Social Benefit Reforms in Three European Countries, 19802006. Helsinki: Kela, Research Department, 2008.

Jaakkola, Jouko. Armeliaisuus, yhteisöapu, sosiaaliturva: Suomalaisen sosiaalisen turvan historia. Helsinki: Sosiaaliturvan keskusliitto, 1994.

Jensen-Eriksen, Niklas, Henrik Tala, Elina Kuorelahti, Aaro Sahari ja Maiju Wuokko. Loputtomat

kihlajaiset: Yritykset ja kolmikantakorporatismi Suomessa 1940-2020. Helsinki: Kustannusosakeyhtiö Siltala, 2020.

Julkunen, Raija. Suunnanmuutos: 1990-luvun sosiaalipolittinen reformi Suomessa. Tampere: Vastapaino, 2001.

Kalela, Jorma. Työttömyys 1900-luvun suomalaisessa yhteiskuntapolitiikassa. Helsinki: Valtion painatuskeskus, 1989.

Kangas, Olli ja Tapani Paavonen. Suomen eduskunta 100 vuotta. Osa 8, Eduskunta hyvinvointivaltion rakentajana. Helsinki: Edita, 2006.

Kari, Markus. Suomen rahoitusmarkkinoiden murros 1980-luvulla. Helsinki: Into, 2016.

Koistinen, Pertti. Työ, työvoima ja politiikka. Tampere: Vastapaino, 2014.

Kärrylä, Ilkka. "The Contested Relationship of Democracy and Economy: Debates on Economic and Industrial Democracy in Finland and Sweden, 1960s-1990s." Väitöskirja, Helsingin yliopisto, 2019.

Mansner, Markku. Suomalaista yhteiskuntaa rakentamassa: Suomen työnantajain keskusliitto 1980-1992. Helsinki: Elinkeinoelämän keskusliitto, 2005. 
Marttila, Arla Helena. "Aktivointipolitiikka yhteisöreaktiona." Pro gradu -tutkielma, Helsingin yliopisto, 2016.

Nenonen, Marko. Lapiolinjalla: Työttömät pakkotöissä 1948-1971. Jyväskylä: Atena, 2006.

Outinen, Sami. "From Steering Capitalism to Seeking Market Acceptance." Scandinavian Journal of History 42, no 4 (June 2017): 389-413. http://doi.org/10.1080/03468755.2017.1336599.

Outinen, Sami. Sosiaalidemokraattien tie talouden objailusta markkinareaktioiden ennakointiin: työllisyys sosiaalidemokraattien politiikassa Suomessa 1975-1998. Helsinki: Into-Kustannus, 2015.

Savtschenko, Ritva. Kompuroiden korporatismissa: Eheytyneen SAK:n ristipaineet suomalaisessa korporatismissa 1968-1978. Omakustanne, 2015.

Suoranta, Anu. Halvennettu työ: Pätkätyö ja sukupuoli sopimusyhteiskuntaa edeltävissä työmarkkinakäytännöissä. Tampere: Vastapaino, 2009.

Urponen, Kyösti. "Huoltoyhteiskunnasta hyvinvointivaltioon." Teoksessa Armeliaisuus, yhteisöapu, sosiaaliturva: suomalaisten sosiaalisen turvan historia, kirjoittanut Jouko Jaakkola, Panu Pulma, Mirja Satka ja Kyösti Urponen, 163-260. Helsinki: Sosiaaliturvan keskusliitto, 1994.
Wuokko, Maiju. "Markkinatalouden etujoukot: Elinkeinoelämän valtuuskunta, Teollinen keskusliitto ja liike-elämän poliittinen toiminta 1970-1980-lukujen Suomessa." Väitöskirja, Helsingin yliopisto, 2016.

Wuokko, Maiju. "The curious compatability of consensus, corporatism, and neoliberalism: The Finnish business community and the retasking of a corporatist welfare state." Business History (April 2019): 1-18.

https://doi.org/10.1080/00076791.2019.1598379.

Wuokko, Maiju. "Riitaisa liitto 1956-1991." Osa 2 teoksessa Loputtomat kihlajaiset: Yritykset ja kolmikantakorporatismi Suomessa 1940-2020, 147-284. Helsinki: Kustannusosakeyhtiö Siltala, 2020.

Vähätalo, Kari. Työttömät ja työttömyysturvauudistus: Tutkimus vuoden 1985 työttömyysturvaundistuksen työvoima- ja sosiaaliturvapoliittisista vaikutuksista. Helsinki: Työvoimaministeriö, 1988.

Yliaska, Ville. Tehokkuuden toiveuni: Uuden julkisjohtamisen historia Suomessa 1970-luvulta 1990-luvulle. Helsinki: Into, 2014. 